総 説

特集：創薬から見た免疫疾患の新たな治療ターゲット

p38 MAP Kinase 阻害薬

\author{
西川昌孝, 名井陽, 冨田哲也
}

高樋康一郎, 南平 昭 豪, 吉川秀 樹

\title{
p38 MAP Kinase inhibitor
}

\author{
Masataka NiSHIKAWA ${ }^{* 1}$, Akira MYoui ${ }^{* 2}$, Tetsuya ToMiTA*2, \\ Koichiro TAKAHI ${ }^{* 3}$, Akihide NAMPEI ${ }^{* 2}$ and Hideki YosHIKAWA ${ }^{* 2}$ \\ ${ }^{*}$ Department of Orthopaedic Surgery, Toyonaka Municipal Hospital \\ ${ }^{*}$ Department of Orthopaedics, Osaka University Graduate School of Medicine \\ ${ }^{*}$ Department of Orthopaedic Surgery, Osaka Koseinennkin Hospital
}

(Received August 7, 2007)

summary

FR167653 is a potent inhibitor of p38 MAP Kinase and inhibits TNF- $\alpha$ and IL-1 $\beta$ production in inflammatory cells. In this study we investigated the effect of FR167653 on CIA.

CIA rats were subcutaneously injected with FR167653 $(32 \mathrm{mg} / \mathrm{kg} /$ day $)$ starting on the day of the booster injection and after the onset of arthritis in the prophylactic and therapeutic treatment groups, respectively. The hind paw swelling, radiolographic and histologic scores, and osteoclast number were evaluated. Serum and tissue cytokine levels were assessed by ELISA. Flow cytometric analysis of T-lymphocytes from bone marrow was also performed. The effect of FR167653 on in vitro osteoclast formation induced by sRANKL and TNF- $\alpha$ was examined. Hind paw swelling occurred in CIA rats but not in the prophylactic treatment group. Therapeutic treatment also significantly reduced the paw swelling. The mean radiographic, histologic score, and osteoclast number of the treatment group were significantly lower than those of CIA rats without treatment. FR167653 treatment reduced serum TNF- $\alpha$ and IL-1 $\beta$ levels, ankle IL-1 $\beta$ concentration, and CD4-CD8a + T-cell population in bone marrow. Furthermore, FR167653 inhibited the osteoclastlike cell differentiation induced by both SRANKL and TNF- $\alpha$ in vitro.

FR167653 prevented the onset of arthritis in a prophylactic treatment model and suppresses the progression of joint destruction in a therapeutic treatment model, suggesting that p38 MAP Kinase is a potential therapeutic target for rheumatoid arthritis.

Key words - Rheumatoid Arthritis; Collagen-induced arthritis; p38 MAP Kinase; TNF- $\alpha$; IL-1 $\beta$

抄 録

p38 MAP Kinase は TNF- $\alpha, \mathrm{IL}-1 \beta$ などの炎症性サイトカイン共通細胞内シグナル伝達分子であり，関節リウマ チでの関節炎，骨関節破壊に重要な役割を担っていると考えられている．FR167653 は p38 MAP Kinase 選択的阻 害薬であり炎症性細胞からの TNF- $\alpha, \mathrm{IL}-1 \beta$ の産生を阻害する。今回，関節リウマチの動物モデルである CIA ラ ットに対し FR167653 を投与しその効果を検討した. CIA ラット群では足関節の腫脹, 関節破壊, 関節周囲の破骨 細胞数増加がみられたが，阻害薬投与群では予防投与群のみならず治療投与群においてもすべての点で著しい改善 がみられた。 また，血清中抢よび組織中の炎症性サイトカイン濃度も CIA ラット群と比較して著しく低下してい た．骨髄細胞からの in vitro 破骨細胞誘導実験に抢いても FR167653 は破骨細胞分化を著しく抑制した．今回の実 験モデルに掞いて p38MAP Kinase 阻害薬であるFR167653 は複数の炎症性サイトカインの産生を抑制し, また破 骨細胞分化抑制を介して骨関節破壊を直接抑制することがわかった。をた骨䯣リンパ球に対しても何らかの影響を 及ぼしていることも示唆された。これらの結果は，関節リウマチに挄いて p38 MAP Kinase が重要な治療ターゲッ トになりうる可能性を示している.

\footnotetext{
*1市立豊中病院整形外科

$*_{2}$ 大阪大学大学院医学系研究科器官制御外科学整形外科

*3大阪厚生年金病院整形外科
}

\section{はじめに}

関節リウマチは全身関節破壊を引き起こす慢性進 行性の免疫性炎症過程が特徵とされる 
$\mathrm{TNF}-\alpha, \mathrm{IL}-1 \beta, \mathrm{IL}-6, \mathrm{IL}-8$ などの炎症性サイトカイ ンやこれらのサイトカインから誘導される蛋白分解 酵素が関節リウマチの病因に扔いて重要であること が過去に多数報告されている2 5). 関節リウマチや その動物モデルで生じる骨びらんの組織病理的特徵 は炎症性関節炎での局所，辺縁，および軟骨下骨で の骨消失に破骨細胞が重要な役割を担っていること を強力に示唆している6 . また最近，これらに加え て receptor activator of nuclear factor $\kappa \mathrm{B}$ (RANK) ligand や TNF- $\alpha$ により誘導される破骨細胞が原因 の骨破壞も関節リウマチの骨・関節破壊において重 要な役割を示していることが報告されている7 11).

コラーゲン関節炎 (Collagen-induced arthritis : CIA）は多くの組織病理的特徵が関節リウマチと共 通しており多発性関節炎の実験モデルとして広く用 いられている。またCIAの病因に抢いて関節リウ マチ同様 $\mathrm{TNF}-\alpha, \mathrm{IL}-1 \beta$ や IL-6, IL-8 が重要な役 割を担っていることが報告されている5,12 15). p38 mitogen-activated protein (MAP) Kinase は TNF- $\alpha$, IL-1 $\beta$ や RANK ligand 共通の細胞内シグナル伝達 分子であり1,16)，関節リウマチでの骨関節破壊に重 要な役割を担っていると考えられている．本稿では CIA ラットに抢ける関節炎抢よび骨関節破壊に対 する p38 MAP Kinase 阻害薬の抑制効果を評価し 関節リウマチ治療への応用の可能性を検討する.

\section{予防投与モデルにおける CIA ラットの骨関節破壊 抑制効果}

CIA は bovine type II collagen と Freund's incomplete adjuvant を 6 週齢䧳のルイスラットに 0 日目 および 7 日目に感作させることにより誘導し
た ${ }^{17,18)}$.このモデルでは通常 18-21 日目に肉眼的に 関節炎が確認される. 今研究では p38 MAP Kinase 阻害薬としてFR167653 を使用した（藤沢製薬：現 アステラス製薬提供).

予防投与モデル（0-35 日）では FR167653 をコ ラーゲン感作日（7日目）から 4 週間（35日目まで） 連日皮下投与 $(32 \mathrm{mg} / \mathrm{kg} /$ 日) を行った. コントロー ルである CIA ラット群では 21 日目までに最大の足 関節腫脹 $\left(2.22 \mathrm{~cm}^{3}\right)$ が生じその後徐々に減少した が，阻害薬投与群ではほとんどのラットで足関節腫 脹は見られなかった（図 1).

また実験系の最終日（35 日目）にラットの足関 節のレントゲン評価 ${ }^{19)}$ および組織学的評価20)を行い 点数化した. CIA ラット群の足関節のレントゲン では活発な関節炎や骨破壊をしめす重度の骨吸収や 骨びらんが見られた. 組織学的には CIA ラット群 では関節軟骨の消失と炎症性細胞の浸潤, TRAP 陽性破骨細胞数の増加が見られたが阻害薬投与群で はこれらの所見は著しく改善されていた（図2）。

レントゲンスコアーは CIA ラット群（3.0）が阻 害薬投与群 $(0.3)$ より有意に高值であり, 組織学 的スコアーは阻害薬投与群 (1.0) が CIA ラット群 （3.2）より有意に減少していた。 また足関節周囲の 破骨細胞数は阻害薬投与群（20.9）が CIA ラット 群（107.5）より有意に減少していた（表 1).

\section{治療投与モデルにおける CIA ラットの骨関節破壊 抑制効果}

次に関節炎発症後での p38 MAP Kinase 阻害薬 の効果を評価するため治療投与モデル（0-49 日） での実験を行った．治療投与モデルでは関節炎発症

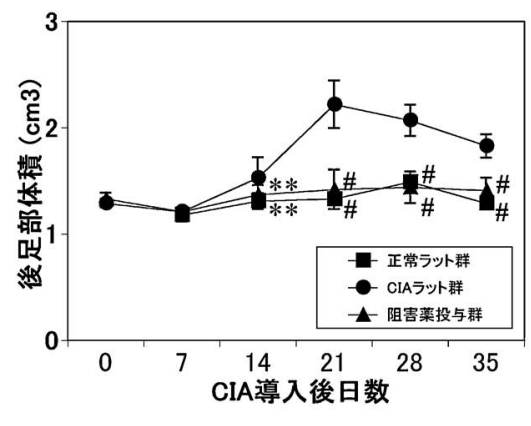

a: 予防投与モデル

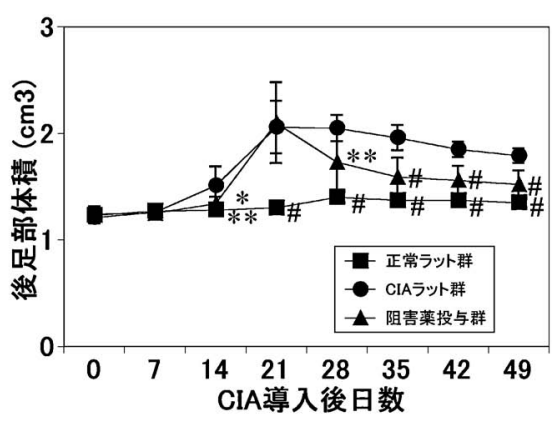

$b$ : 治療投与モデル

図 1 CIA ラットの後足関体積の経時的変化

予防投与モデル, 治療投与モデルの両群に拉いて p38 MAPK 阻害薬である FR167653 の投与によって関節炎の発症及びその進 行が著しく抑制された。

${ }^{*} \mathrm{p}<0.05{ }^{* *} \mathrm{p}<0.01 \quad \# \mathrm{p}<0.0001$ vs CIA ラット群 


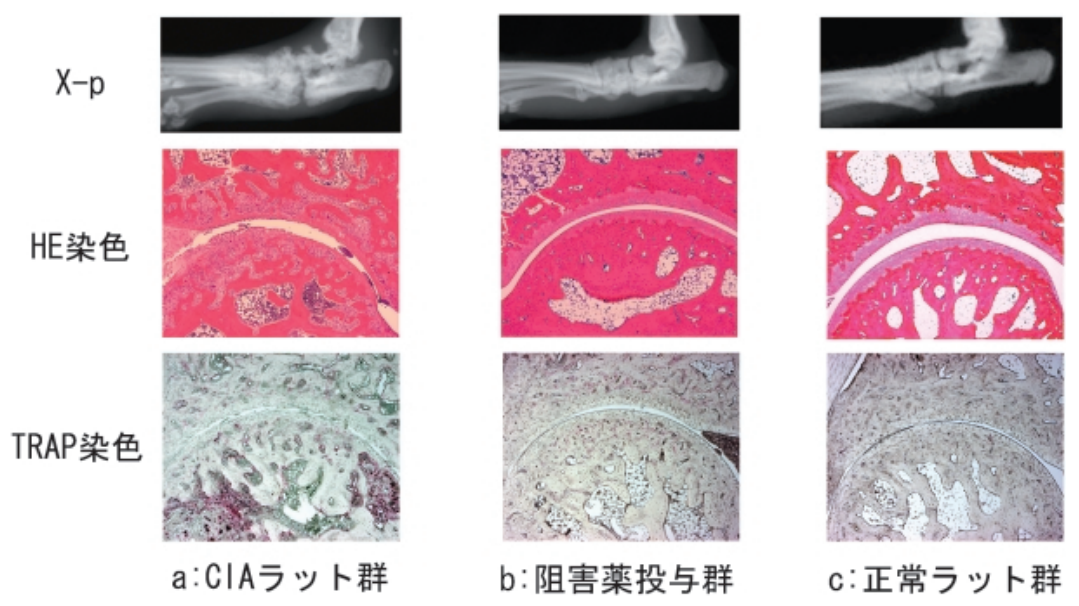

図 2 予防投与モデルに抢ける骨関節破壊抑制効果

CIA ラットの足関節 X-p，HE 染色，TRAP 染色では活発な関節炎や骨破壊をしめす重度の骨吸收や骨びらんが見られた。こ れに対し p38 MAP Kinase 阻害薬投与群ではほほ正常ラットと同様の所見であった。



a:CIAラット群

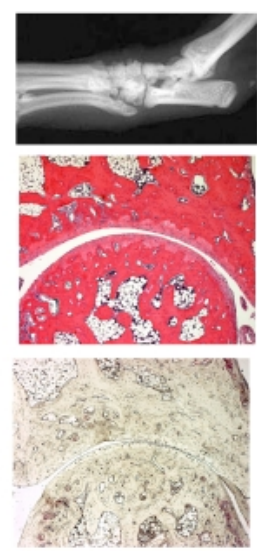

$\mathrm{b}$ : 阻害薬投与群

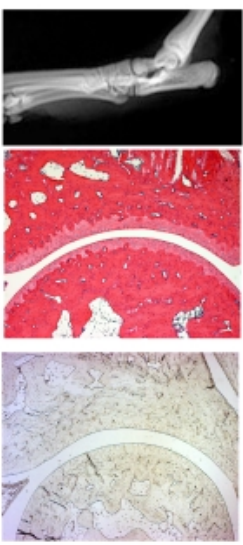

c:正常ラット群

図 3 治療投与モデルにおける骨関節破壊抑制効果

予防投与モデルと同様に p38 MAP Kinase 阻害薬投与群では骨関節破壊は著しく抑制されていた.
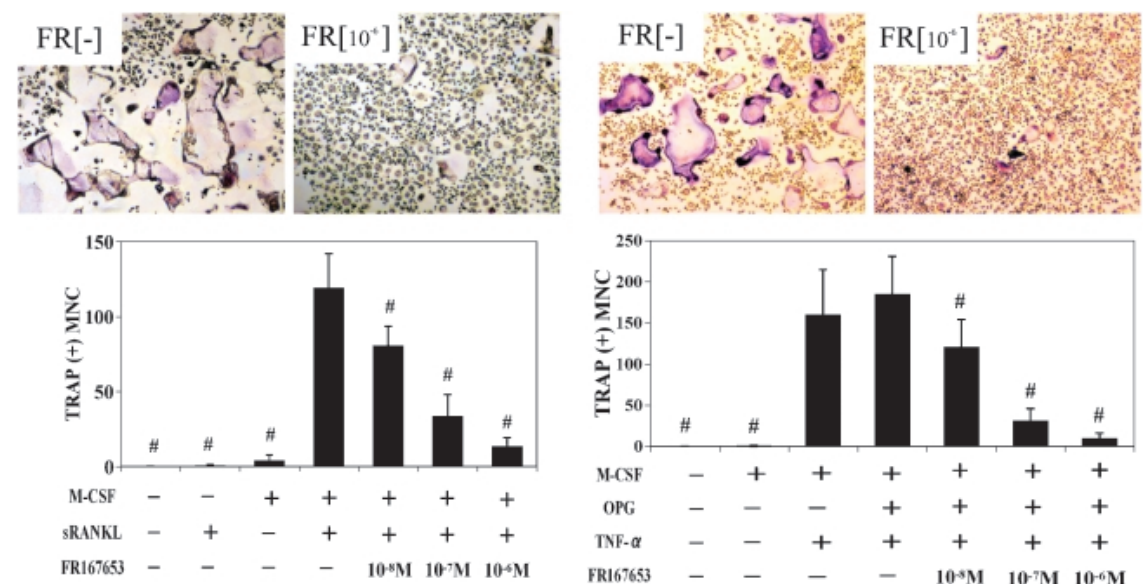

図 4 骨髄細胞の破骨細胞分化に対する抑制効果

soluble RANK ligand 及び TNF- $\alpha$ によるラット骨髄細胞からの TRAP 陽性多核細胞形成は p38 MAP Kinase 阻害薬である FR167653により濃度依存的にほぼ完全に阻害された。 
表 1 予防投与モデルでの局所評価

\begin{tabular}{ccccc}
\hline \hline & 関節数 & レントゲンスコアー & 組織学的スコアー & 破骨細胞数 \\
\hline CIA ラット群 & 12 & $3.0 \pm 0.0$ & $3.2 \pm 0.5$ & $107.5 \pm 55.0$ \\
阻害薬投与群 & 16 & $0.3 \pm 0.7^{\#}$ & $1.0 \pm 0.8^{\#}$ & $20.9 \pm 38.7^{* *}$ \\
正常ラット群 & 8 & $0.0 \pm 0.0^{\#}$ & $0.0 \pm 0.0^{* * *}$ & $1.8 \pm 2.2^{* *}$ \\
\hline
\end{tabular}

平均值士標準偏差 $(\mathrm{SD}),{ }^{* *} p<0.01,{ }^{* * *} p=0.0001,{ }^{*} p<0.0001$ vs CIA ラット群

表 2 治療投与モデルでの局所評価

\begin{tabular}{ccccc}
\hline \hline & 関節数 & レントゲンスコアー & 組織学的スコアー & 破骨細胞数 \\
\hline CIA ラット群 & 13 & $2.9 \pm 0.3$ & $3.3 \pm 0.6$ & $90.0 \pm 44.5$ \\
阻害薬投与群 & 10 & $1.3 \pm 0.8^{\#}$ & $1.2 \pm 0.9^{* * *}$ & $9.7 \pm 8.9^{\#}$ \\
正常ラット群 & 14 & $0.0 \pm 0.0^{\#}$ & $0.0 \pm 0.0^{\#}$ & $1.0 \pm 1.8^{\#}$ \\
\hline
\end{tabular}

平均值土標準偏差 (SD), ${ }^{* * *} p=0.0001,{ }^{*} p<0.0001$ vs CIA ラット群

表 3 血清中炎症性サイトカイン濃度（予防投与モデル）

\begin{tabular}{cccc}
\hline \hline & ラット数 & $\mathrm{TNF}-\alpha(\mathrm{pg} / \mathrm{ml})$ & $\mathrm{IL}-1 \beta(\mathrm{pg} / \mathrm{ml})$ \\
\hline CIA ラット群 & 6 & $66.7 \pm 25.2$ & $116.6 \pm 35.8$ \\
阻害薬投与群 & 5 & $3.16 \pm 7.1^{* * *}$ & 検出限界以下**+ \\
正常ラット群 & 4 & 検出限界以下**+ & 検出限界以下**+ \\
\hline 平均值士標準偏差 $(\mathrm{SD}),{ }^{* *} p<0.01$ vs CIA ラット群, †統計処理上検出限界以下は 0.0 とてし評価
\end{tabular}

表 4 足関節中炎症性サイトカイン濃度（予防投与モデル）

\begin{tabular}{cccc}
\hline \hline & 関節数 & $\mathrm{TNF}-\alpha(\mathrm{pg} / \mathrm{mg})$ & $\mathrm{IL}-1 \beta(\mathrm{pg} / \mathrm{mg})$ \\
\hline CIA ラット群 & 6 & $0.060 \pm 0.013$ & $2.448 \pm 0.610$ \\
阻害薬投与群 & 6 & $0.056 \pm 0.012$ & $0.450 \pm 0.067^{\sharp}$ \\
正常ラット群 & 6 & $0.052 \pm 0.045$ & $0.187 \pm 0.090^{\sharp}$ \\
\hline
\end{tabular}

平均值土標準偏差 $(\mathrm{SD}),{ }^{*} p<0.0001$ vs CIA ラット群

後（21 日目）から阻害薬を 4 週間（49 日目まで） 連日皮下投与した。このモデルでも足関節腫脹は阻 害薬投与群 $\left(1.73 \mathrm{~cm}^{3}: 28\right.$ 日目, $1.59 \mathrm{~cm}^{3}: 35$ 日目 $)$ で CIA ラット $\left(2.05 \mathrm{~cm}^{3}: 28\right.$ 日目, $1.96 \mathrm{~cm}^{3}: 35$ 日目）と比較してほぼ正常レベルまで改善する有意 な効果を示した（図 1). またレントゲン，組織学 的所見も著しく改善し（図 3)，レントゲンスコアー および組織学的スコアーは CIA ラット群 $(2.9,3.3)$ と比較して阻害薬投与群 $(1.3,1.2)$ では有意に低 值であった。また足関節周囲の破骨細胞数も阻害薬 投与群（9.7）が CIA ラット群（90.0）より有意に 減少していた（表 2).

\section{炎症性サイトカイン産生抑制}

p38 MAP Kinase 阻害薬の全身及び関節局所にお ける影響を検討するために予防投与群での血清及び 組織中炎症性サイトカイン濃度を測定した。CIA
ラット群では血清中 $\mathrm{TNF}-\alpha, \mathrm{IL}-1 \beta$ 濃度と足関節骨 軟部組織中 IL- $1 \beta$ 濃度が上昇していた. しかし阻 害薬投与群ではいずれも著しく低值を示し炎症性サ イトカイン産性が抑制されていることが確認された (表 3，4）。このことにより p38 MAP Kinase 阻害薬 は炎症性サイトカインの産生を抑制することにより 関節炎症状を改善していることが示唆された。

\section{破骨細胞分化に対する抑制効果}

CIA ラットでの p38 MAP Kinase 阻害薬による 破骨細胞数減少が組織学的に確認されたため, macrophage colony-stimulating factor $(\mathrm{M}-\mathrm{CSF})$ 存 在下での soluble RANK ligand 及び TNF- $\alpha$ による in vitro 破骨細胞分化誘導実験 ${ }^{21)}$ を行い，そのメ力 ニズムを検討した. soluble RANK ligand によるラ ット骨髄細胞からの TRAP 陽性多核細胞形成は p38 MAP Kinase 阻害薬により濃度依存的にほぼ完 


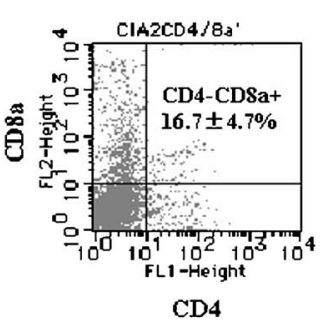

a:CIAラット群

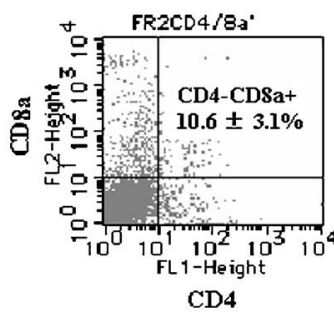

$b$ : 阻害薬投与群

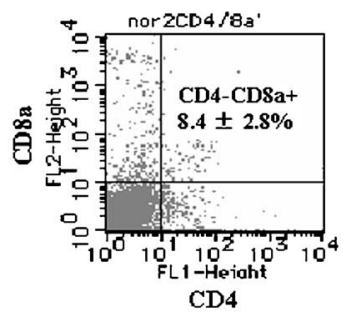

$c:$ 正常ラット群

図 5 予防投与モデルにおける骨髄リンパ球に対する影響

$\mathrm{CD} 4$ 陰性 CD8 陽性 T 細胞の割合が CIA ラット群で有意に増加しており, p38 MAP Kinase 阻害薬投与群ではその割合はほぼ 正常ラットと同レベルであった.

全に阻害された。あたこの阻害薬は RANK ligand の選択的 decoy である osteoprotegerin (OPG) 存 在下での TNF- $\alpha$ による TRAP 陽性多核細胞形成を も同様に阻害した（図 4)。これらのデータは恐ら $<$ p38 MAP Kinase 阻害薬が破骨細胞前駆細胞に 対して作用し，これらの独立した $2 つ の$ 経路22,23)の 破骨細胞形成を直接的に阻害することを示している と考えられる。

\section{骨髄リンパ球に対する影響}

骨髄中での CD4 陽性 T 細胞の増加が関節リウマ チやCIA の病因に関連している可能性が過去に報 告されている24 27)．今回骨髄リンパ球に対する p38 MAP Kinase 阻害薬の影響を検討するため予防 投与モデルラット骨䯣細胞を flow cytometry にて 解析した。その結果, CD4 陰性 CD8 陽性 $\mathrm{T}$ 細胞の 割合が CIA ラット群（16.7\%）で有意に増加して おり，p38 MAP Kinase 阻害薬投与群 (10.6\%) で はその割合はほぼ正常ラット $(8.4 \%)$ と同レベル であった（図 5)。この結果は CD4 陰性 CD8 陽性 $\mathrm{T}$ 細胞が CIA の発症に何らかの役割を果たしてお り，阻害薬の投与により局所骨䯣への CD4 陰性 $\mathrm{CD} 8$ 陽性 $\mathrm{T}$ 細胞の蓄積が阻害された可能性を示し ている.

\section{関節リウマチ治療へ展望}

p38 MAP Kinase は TNF- $\alpha$ や IL- $1 \beta$ などの炎症 性サイトカインを制御しており, p38 MAP Kinase 阻害薬の炎症性疾患に対する優れた効果が過去に多 数報告されている $\left.{ }^{28} 37\right)$. 我々は p38 MAP Kinase 阻害薬であるFR167653 が CIA の発症を完全に抑 制し，また関節炎発症後でも著しく関節炎症状を改 善し骨・関節破壊を抑制させることを初めて証明し た ${ }^{38)}$. CIA ラットの体内では炎症性サイトカイン
の産性が増加しており，さらにそれらの炎症性サイ トカインがさらに他の炎症性サイトカインの産生を 促す悪循環メカニズムが生じている。p38 MAP Kinase 阻害薬は直接的に炎症性サイトカインの産 生を抑制するだけでなく，これらの悪循環入カニズ ムをも阻害することにより血清及び組織中の炎症性 サイトカイン濃度の著しい減少を引き起こしたと考 えられる．またこれらの炎症性サイトカインの産生 抑制は間接的に炎症性サイトカインによる破骨細胞 分化を抑制するが, p38 MAP Kinase 阻害薬は破骨 細胞前駆細胞への直接作用によっても破骨細胞分化 を抑制することから，これらの協調作用により強力 に骨破壊が抑制されたと考えられる。 また今研究で は阻害薬投与群で CD4 陰性 CD8 陽性 $\mathrm{T}$ 細胞の骨 髄中での割合が CIA ラット群に比較して減少して いた。これは阻害薬投与により局所骨髄への CD4 陰性 CD8 陽性 $\mathrm{T}$ 細胞の蓄積が阻害された可能性が 考えられCIAの発症に何らかの影響を及ぼした 可能性がある。p38 MAP Kinase 阻害薬である FR167653 は CIA ラットにおいて関節炎の発症を阻 害し関節破壊の進行を抑制した。これらの結果は, 関節リウマチに抢いて p38 MAP Kinase が重要な 治療ターゲットになりうる可能性を示している.

おわりに

近年, 関節リウマチの治療において抗 TNF- $\alpha$ 抗 体を中心とした生物製剤が使用され優れた成績が報 告されている39 47)。しかし，これらの製剂は高価 であり，投与に際して入院加療が必要なことも少な くない，また，これらの蛋白製剤に対する自己抗体 産生の結果, 効果の減弱やアレルギー反応も報告さ れている48 50). これに対して今回使用した FR167653 などの合成低分子シグナル作動薬は製造 コストが安価であり, 自己抗体産生のリスクも少な 
い.関節リウマチ治療において生物製剂と並んでこ のような p38 MAP Kinase 阻害薬が重要な治療薬 になりうる可能性があると考えられる.

\section{文献}

1) Suzuki M, Tetsuka T, Yoshida $S$, Watanabe N, Kobayashi M, Matsui M, et al. : The role of p38 mitogen-activated protein kinase in IL-6 and IL- 8 production from the TNF- $\alpha-$ or IL- $1 \beta-$ stimulated rheumatoid synovial fibroblast. FEBS Lett 465 : 23-27, 2000.

2) Feldmann M, Brennan FM, Maini RN. : Role of cytokines in rheumatoid arthritis. Annu Rev Immunol 14 : 397-440, 1996.

3) Feldmann M, Brennan FM, Maini RN : Rheumatoid arthritis. Cell $85:$ 307-310, 1996.

4) Durie FH, Fava RA, Noelle R. : Short analytical review: Collagen-induced arthritis as a model of rheumatoid arthritis. Clin Immunol Immunopathol 73 : 11-18, 1994.

5) Sasai M, Saeki Y, Ohshima S, Nishioka K, Mima T, Tanaka T, et al. : Delayed onset and reduced severity of collagen-induced arthritis in interleukin-6-deficient mice. Arthritis Rheum 42 : 1635-1643, 1999.

6) Goldring SR, Gravallese EM. : Pathogenesis of bone lesions in rheumatoid arthritis. Curr Rheumatol Rep 4 : 226-231, 2000.

7) Kong YY, Feige U, Sarosi I, Bolon B, Tafuri A, Morony $\mathrm{S}$, et al. : Activated $\mathrm{T}$ cells regulate bone loss and joint destruction in adjuvant arthritis through osteoprotegerin ligand. $\mathrm{Na}$ ture 18 : 304-309, 1999.

8) Romas E, Gillespie MT, Martin TJ. : Involvement of receptor activator of $\mathrm{NF} \kappa \mathrm{B}$ ligand and tumor necrosis factor $-\alpha$ in bone destruction in rheumatoid arthritis. Bone 30 : 340-346, 2002.

9) Arend WP, Dayer J-M. : Inhibition of the production and effects of Interleukin-1 and tumor necrosis factor $\alpha$ in rheumatoid arthritis. Arthritis Rheum 38 : 151-160, 1995.

10) Feldmann M, Elliot MJ, Woody JN, Maini RN. : Anti-tumor necrosis factor- $\alpha$ therapy of rheumatoid arthritis. Adv Immunol 64 : 283350, 1997.

11) Breedveld FC. : Future trends in the treatment of rheumatoid arthritis: cytokine targets. Rheumatology 38 Suppl 2 : 11-13, 1998.

12) Van den Berg WB, Joosten LA, Helsen MM, van de Loo FA. : Amelioration of established murine collagen-induced arthritis with anti-IL1 treatment. Clin Exp Immunol 95 : 237-243, 1994.

13) Joosten LAB, Helsen MMA, van de Loo FAJ, van den Berg WB. : Anticytokine treatment of established type II collagen-induced arthritis in DBA/1 mice : a comparative study using anti$\mathrm{TNF} \alpha$, anti-IL- $1 \alpha / \beta$, and IL-1R $\alpha$. Arthritis Rheum 39 : 797-809, 1996.

14) Mussener A, Litton MJ, Lindroos E, Klareskog L. Cytokine production in synovial tissue of mice with collagen-induced arthritis (CIA). Clin Exp Immunol 107 : 485-493, 1997.

15) Marinova-Mutafchieva L, Williams RO, Mason LJ, Mauri C, Feldmann M, Maini RN : Dynamics of proinflammatory cytokine expression in the joints of mice with collagen-induced arthritis (CIA). Clin Exp Immunol 107 : 507512, 1997.

16) Miyazawa $K$, Mori A, Miyata H, Akahane M, Ajisawa Y, Okudaira H. : Regulation of interleukin-1- $\beta$-induced interleukin-6 gene expression in human fibroblast-like synoviocytes by p38 mitogen-activated protein kinase. $\mathrm{J}$ Biol Chem 273 : 24832-24838, 1998.

17) Trentham D, Townes A, Kang A.: Autoimmunity to type II collagen : an experimental model of arthritis. J Exp Med 146 : 857-868, 1977.

18) Tomita $\mathrm{T}$, Takeuchi E, Tomita N, Morishita R, Kaneko M, Yamamoto K, at al. : Suppressed severity of collagen-induced arthritis by in vivo transfection of nuclear factor $\kappa \mathrm{B}$ decoy oligodeoxynucleotides as a gene therapy. Arthritis Rheum 42 : 2532-2542, 1999.

19) Cuzzocrea S, Mazzon E, Dugo L, Serraino I, Britti D, De Maio M, et al. : Absence of endogenous interleukin-10 enhances the evolution of murine type-II collagen-induced arthritis. Eur Cytokine Netw 12 : 568-580, 2001.

20) Shiozawa S, Shimizu K, Tanaka K, Hino K. : Studies on the contribution of c-fos/AP-1 to arthritic joint destruction. J Cin Invest 99: 1210-1216, 1997.

21) Takeshita S, Kaji K, Kudo A. : Identification and characterization of the new osteoclast progenitor with macrophage phenotypes being able to differentiate into mature osteoclasts. $J$ Bone Miner Res 15 : 1477-1488, 2000.

22) Matsumoto $M$, Sudo $T$, Saito $T$, Osada $H$, Tsujimoto M. : Involvement of p38 mitogen- 
activated protein kinase signaling pathway in osteoclastogenesis mediated by receptor activator of NF- $\kappa$ B ligand (RANKL). J Biol Chem 275 : 31155-31161, 2000.

23) Matsumoto M, Sudo T, Maruyama M, Osada H, Tsujimoto M. : Activation of p38 mitogenactivated protein kinase is crucial in osteoclastogenesis induced by tumor necrosis factor. FEBS Lett $486: 23-28,2000$.

24) Kong YM, Waldmann H, Cobbold S, Giraldo AA, Fuller BE, Simon LL. : Pathogenic mechanisms in murine autoimmune thyroiditis : short- and long-term effects of in vivo depletion of $\mathrm{CD}^{+}$and $\mathrm{CD}^{+}$cells. Clin Exp Immunol 77 : 428-433, 1989.

25) Mozes E, Kohn LD, Hakim F, Singer DS. : Resistance of MHC class I-deficient mice to experimental systemic lupus erythematosus. Science 261 : 91-93, 1993.

26) Zhang GX, Ma CG, Xiao BG, Bakhiet M, Link $\mathrm{H}$, Olsson T. : Depletion of CD8 ${ }^{+} \mathrm{T}$ cells suppresses the development of experimental autoimmune myasthenia gravis in Lewis rats. Eur J Immunol 25 : 1191-1198, 1995.

27) Tada Y, Ho A, Koh D, Mak TW. : Collagen-induced arthritis in CD4- or CD8-deficient mice : $\mathrm{CD} 8^{+} \mathrm{T}$ cells play a role in initiation and regulate recovery phase of collagen-induced arthritis. J Immunol 156 : 4520-4526, 1996.

28) Yamamoto N, Sakai F, Yamazaki H, Nakahara K, Okuhara M. : Effect of FR167653, a cytokine suppressive agent, on endotoxin-induced disseminated intravascular coagulation. Eur J Pharmacol 314 : 137-142, 1996.

29) Yamamoto N, Sakai F, Yamazaki H, Nakahara K, Okuhara M. : FR167653, a dual inhibitor of interleukin-1 and tumor necrosis factor-alpha, ameliorates endotoxin-induced shock. Eur $J$ Pharmacol 327 : 169-175, 1997.

30) Takahashi S, Keto $Y$, Fujita T, Uchiyama T, Yamamoto A. : FR167653, a p38 mitogenactivated protein kinase inhibitor, prevents Helicobacter pylori-induced gastritis in Mongolian gerbils. J Pharmacol Exp Ther 296 : 4856, 2001.

31) Kawashima Y, Takeyoshi I, Otani Y, Koibuchi Y, Yoshinari D, Koyama T. et al. : FR 167653 attenuates ischemia and reperfusion injury of the rat lung with suppressing p38 mitogen-activated protein kinase. $J$ Heart Lung Transplant 20 : 568-574, 2001.
32) Yoshinari D, Takeyoshi I, Koibuchi, Matsumoto K, Kawashima Y, Koyama T, et al. : Effects of a dual inhibitor of tumor necrosis factor- $\alpha$ and interleukin-1 on lipopolysaccharide-induced lung injury in rats : Involvement of the p38 mitogen-activated protein kinase pathway. Crit Care Med 29 : 628-634, 2001.

33) Badger AM, Griswold DE, Kapadia R, Blake S, Swift BA, Hoffman SJ, et al. : Diseasemodifying activity of SB242235, a selective inhibitor of p38 mitogen-activated protein kinase, in rat adjuvant-induced arthritis. Arthritis Rheum 43 : 175-183, 2000.

34) Shinozaki $T$, Takagishi $K$, Tsutsumi S, Yanagawa $\mathrm{T}$, Takeuchi $\mathrm{K}$, Watanabe $\mathrm{H}$, et al. : Effect of FR167653, a dual inhibitor of interleukin-1 and tumor necrosis factor, on adjuvant arthritis in rats. Mod Rheumatol $11: 300-303,2001$.

35) Aiba M, Takeyoshi I, Sunose Y, Iwazaki S, Tsutsumi H, Ohwada S, et al. : FR167653 ameliorates pulmonary damage in ischemiareperfusion injury in a canine lung transplantation model. J Heart Lung Transplant 19 : 879886, 2000.

36) Kobayashi N, Kataoka T, Ono A, Tsukimi Y, Okabe S. : Role of p38 mitogen-activated protein kinase in the healing of gastric ulcers in rats. J Physiol Pharmacol 52 : 195-210, 2001.

37) Kitada H, Sugitani A, Yamamoto H, Otomo N, Okabe Y, Inoue S, et al. : Attenuation of renal ischemia-reperfusion injury by FR167653 in dogs. Surgery 131 : 654-662, 2002.

38) Nishikawa M, Myoui A, Tomita $\mathrm{T}$ et al. : Prevention of the onset and progression of collagen-induced arthritis in rats by the potent $\mathrm{p} 38$ mitogen-activated protein kinase inhibitor FR167653. Arthritis Rheum $48: 2670-2681$, 2003.

39) Brennan FM, Chantry D, Jackson A, Maini R, Feldmann M. : Inhibitory effect of TNF alpha antibodies on synovial cell interleukin-1 production in rheumatoid arthritis. Lancet 2 : 244-247, 1989.

40) Moreland LW, Baumgartner SW, Schiff MH, Tindall EA, Fleishmann RM, Weaver AL, et al. : Treatment of rheumatoid arthritis with a recombinant human necrosis factor receptor (p75)-Fc fusion protein. $N$ Eng $J$ Med 337 : 141-147, 1997.

41) Moreland LW, Cohen SB, Baumgartner SW, Tindall EA, Bulpitt K, Martin R, et al. : Long- 
term safety and efficacy of etanercept in patients with rheumatoid arthritis. J Rheumatol 28 : 1238-1244, 2001.

42) Maini RN, Breedveld FC, Kalden JR, Smolen JS, Davis D, Macfarlane JD, et. al. : Therapeutic efficacy of multiple intravenous infusions of anti-tumor necrosis factor alpha monoclonal antibody combined with low-dose weekly methotrexate in rheumatoid arthritis. Arthritis Rheum 41 : 1552-1563, 1998.

43) Maini R, St Clair EW, Breedveld F, Furst D, Kalden J, Weisman M, et al. : Infliximab (chimeric anti-tumor necrosis factor alpha monoclonal antibody) versus placebo in rheumatoid arthritis patients receiving concomitant methotrexate: a randomised phase III trial. ATTRACT Study Group. Lancet 354 : 19321939, 1999.

44) Kavanaugh A, St Clair EW, McCune WJ, Braakman T, Lipsky P. : Chimeric anti-tumor necrosis factor-alpha monoclonal antibody treatment of patients with rheumatoid arthritis receiving methotrexate therapy. $J$ Rheumatol $27: 841-850,2000$.

45) Elliott MJ, Maini RN, Feldmann M, Kalden JR, Antoni C, Smolen JS, et al. : Randomised double-blind comparison of chimeric monoclonal antibody to tumour necrosis factor $\alpha$ (cA2) versus placebo in rheumatoid arthritis. Lancet 344 : 1105-1110, 1994.

46) Bendele AM, Chlipala ES, Scherrer J, Frazier J, Sennello G, Rich WJ, et al. : Combination benefit of treatment with the cytokine inhibitors interleukin-1 receptor antagonist and PEGylated soluble tumor necrosis factor receptor type I in animal models of rheumatoid arthritis. Arthritis Rheum 43 : 2648-59.

47) Cohen S, Hurd E, Cush J, Schiff M, Weinblatt ME, Moreland LW, et al. : Treatment of rheumatoid arthritis with anakinra, a recombinant human interleukin-1 receptor antagonist, in combination with methotrexate : results of a twenty-four-week, multicenter, randomized, double-blind, placebo-controlled trial. Arthritis Rheum 46 : 614-624, 2002.

48) Bemelmans MHA, Gouma DJ, Buurman WA. : Influence of nephrectomy on TNF receptor clearance in murine model. J Immunol 150 : 2007-2017, 1993.

49) Lipsky PE, Kavanaugh A.: The impact of pharmaco-economic considerations on the utilization of novel anti-rheumatic therapies. Rheumatology 38 Suppl 2 : 41-44, 1999.

50) Kalden JR. : How do the biologics fit into the current DMARD armamentarium? J Rheumatol 28 Suppl $62: 27-35,2001$. 